\title{
Dissolution Behavior of Cellulose in IL + DMSO Solvent: Effect of Alkyl Length in Imidazolium Cation on Cellulose Dissolution
}

\author{
Airong Xu, ${ }^{1}$ Lili Cao, ${ }^{1}$ Bingjun Wang, ${ }^{2}$ and Junying $\mathrm{Ma}^{1}$ \\ ${ }^{1}$ School of Chemical Engineering and Pharmaceutics, Henan University of Science and Technology, Luoyang, Henan 471003, China \\ ${ }^{2}$ China Iron \& Steel Research Institute Group, Beijing 100081, China \\ Correspondence should be addressed to Airong Xu; airongxu@haust.edu.cn
}

Received 22 December 2014; Revised 27 February 2015; Accepted 10 March 2015

Academic Editor: Markku Leskela

Copyright (c) 2015 Airong Xu et al. This is an open access article distributed under the Creative Commons Attribution License, which permits unrestricted use, distribution, and reproduction in any medium, provided the original work is properly cited.

\begin{abstract}
Four cellulose solvents including $\left[\mathrm{C}_{2} \mathrm{mim}\right]\left[\mathrm{CH}_{3} \mathrm{COO}\right]+\mathrm{DMSO},\left[\mathrm{C}_{4} \mathrm{mim}\right]\left[\mathrm{CH}_{3} \mathrm{COO}\right]+\mathrm{DMSO},\left[\mathrm{C}_{6} \mathrm{mim}\right]\left[\mathrm{CH}_{3} \mathrm{COO}\right]+\mathrm{DMSO}$, and $\left[\mathrm{C}_{8} \mathrm{mim}\right]\left[\mathrm{CH}_{3} \mathrm{COO}\right]+$ DMSO were prepared by adding dimethyl sulfoxide DMSO in 1-ethyl-3-methylimidazolium acetate $\left[\mathrm{C}_{2} \mathrm{mim}\right]\left[\mathrm{CH}_{3} \mathrm{COO}\right]$, 1-butyl-3-methylimidazolium acetate $\left[\mathrm{C}_{4} \mathrm{mim}\right]\left[\mathrm{CH}_{3} \mathrm{COO}\right]$, 1-hexyl-3-methylimidazolium acetate $\left[\mathrm{C}_{6} \mathrm{mim}\right]\left[\mathrm{CH}_{3} \mathrm{COO}\right]$, and 1-octyl-3-methylimidazolium acetate $\left[\mathrm{C}_{8} \mathrm{mim}\right]\left[\mathrm{CH}_{3} \mathrm{COO}\right]$, respectively. The solubilities of cellulose in these solvents were determined at $25^{\circ} \mathrm{C}$. The effect of the alkyl chain length in imidazolium cation on cellulose solubility was investigated. With increasing alkyl chain length in imidazolium cation, the solubility of cellulose increases, but further increase in alkyl chain length results in decreases in cellulose.
\end{abstract}

\section{Introduction}

Recently, considerable attention has been received in the research related to the application of imidazolium-based carboxylate ionic liquids (ILs) in the dissolution of cellulose and delignification of lignocellulosic biomass [1]. This is mainly ascribed to the fact that, for the ILs with the same imidazolium-based cation backbone, imidazoliumbased carboxylate ILs generally have lower melting points and higher capacity of cellulose dissolution compared to imidazolium-based chloride or bromide ILs. Fukaya et al. firstly reported the imidazolium-based formate ILs which were liquid at room temperature and could efficiently dissolve cellulose [2]. Xu et al. studied the effect of anionic structure and alkyl chain length of 1-butyl-3-methylimidazolium carboxylate ILs on cellulose solubility and found that cellulose solubility increased due to the replacement of $\mathrm{H}$ in the $\left[\mathrm{CH}_{3} \mathrm{COO}\right]^{-}$anion of $\left[\mathrm{C}_{4} \mathrm{mim}\right]\left[\mathrm{CH}_{3} \mathrm{COO}\right]$ by an electrondonating group but decreased because of the replacement of $\mathrm{H}$ in the $\left[\mathrm{CH}_{3} \mathrm{COO}\right]^{-}$anion of $\left[\mathrm{C}_{4} \mathrm{mim}\right]\left[\mathrm{CH}_{3} \mathrm{COO}\right]$ by an electron-withdrawing group [3, 4]. By NMR spectroscopic studies technique, Zhang et al. studied the dissolution mechanism of cellulose in $\left[\mathrm{C}_{2} \mathrm{mim}\right]\left[\mathrm{CH}_{3} \mathrm{COO}\right]$ and suggested that the hydrogen bonding of hydroxyls with $\left[\mathrm{CH}_{3} \mathrm{COO}\right]^{-}$ anion and $\left[\mathrm{C}_{2} \mathrm{mim}\right]^{+}$cation of $\left[\mathrm{C}_{2} \mathrm{mim}\right]\left[\mathrm{CH}_{3} \mathrm{COO}\right]$ was the major force for cellulose dissolution [5]. $\mathrm{Lu}$ et al. studied the effect of cationic structure of acetate ILs on cellulose dissolution and found that cations with acidic protons but without high electronegativity atoms (like oxygen and/or nitrogen) in the cationic backbone and large sized group in the alkyl chain would be a rational choice [6]. Zhang et al. studied the structure-property relationship of 1-allyl-3-methylimidazolium carboxylate ILs, and the carboxylate ILs had less viscosity and higher cellulose solubility than 1-butyl-3-methylimidazolium carboxylate ILs [7]. Moreover, imidazolium-based carboxylate IL such as $\left[\mathrm{C}_{2} \mathrm{mim}\right]\left[\mathrm{CH}_{3} \mathrm{COO}\right]$ also could be used to dissolve or partition lignocellulosic biomass like wood $[8,9]$.

However, the imidazolium-based carboxylate ILs still show defects: high viscosity which would make cellulose difficultly disperse in ILs and thus help to dissolve cellulose more effectively and high processing temperatures which would consume/waste energy. To overcome the disadvantages, Rinaldi developed (IL + aprotic polar solvent including dimethyl sulfoxide DMSO and DMF) systems which have lower viscosity and higher dissolving rate than 
neat ILs [10]. Later on, $\mathrm{Xu}$ et al. [11] designed novel $\left[\mathrm{C}_{4} \mathrm{mim}\right]\left[\mathrm{CH}_{3} \mathrm{COO}\right] / \mathrm{DMSO}$ solvents by adding an aprotic polar solvent DMSO to $\left[\mathrm{C}_{4} \mathrm{mim}\right]\left[\mathrm{CH}_{3} \mathrm{COO}\right]$ and found that the solvents could effectively dissolve cellulose at ambient temperature without heating. Based on molecular dynamics simulations and quantum chemistry calculations, Zhao et al. investigated the mechanism of cellulose in (IL + aprotic polar solvent) systems and concluded that the solvation of $\left[\mathrm{C}_{4} \mathrm{mim}\right]^{+}$and $\left[\mathrm{CH}_{3} \mathrm{COO}\right]^{-}$by the aprotic solvents makes it possible to produce more "free" $\left[\mathrm{CH}_{3} \mathrm{COO}\right]^{-}$anions from anion-cation pairs, which would readily interact with cellulose, leading to the increase in cellulose solubility [12].

Extensive literature survey reveals that few researches have been conducted to investigate how the alkyl length of imidazolium cation in IL + DMSO solvent effect on cellulose dissolution. To have a better understanding of the alkyl length of imidazolium cation in IL + DMSO solvent effect on cellulose dissolution and provide wealthy knowledge for the design of novel IL + DMSO solvents, more detailed studies are still needed. Therefore, in the present work, four cellulose solvents including $\left[\mathrm{C}_{2} \mathrm{mim}\right]\left[\mathrm{CH}_{3} \mathrm{COO}\right]+\mathrm{DMSO}$, $\left[\mathrm{C}_{4} \mathrm{mim}\right]\left[\mathrm{CH}_{3} \mathrm{COO}\right]+\mathrm{DMSO},\left[\mathrm{C}_{6} \mathrm{mim}\right]\left[\mathrm{CH}_{3} \mathrm{COO}\right]+$ DMSO, and $\left[\mathrm{C}_{8} \mathrm{mim}\right]\left[\mathrm{CH}_{3} \mathrm{COO}\right]+\mathrm{DMSO}$ were designed. The solubilities of cellulose in these solvents will be determined at $25^{\circ} \mathrm{C}$. The effect of the alkyl chain length of imidazolium cation on cellulose solubility will be investigated in detail.

\section{Experimental}

2.1. Materials. Microcrystalline cellulose (MCC) with viscosity-average degree of polymerization (DP) being 229 was from Alfa Aesar. 1-Ethyl-3-methylimidazolium acetate $\left[\mathrm{C}_{2} \mathrm{mim}\right]\left[\mathrm{CH}_{3} \mathrm{COO}\right]$ (99\%), 1-butyl-3-methylimidazolium acetate $\left[\mathrm{C}_{4} \mathrm{mim}\right]\left[\mathrm{CH}_{3} \mathrm{COO}\right]$ (99\%), 1-hexyl-3-methylimidazolium acetate $\left[\mathrm{C}_{6} \mathrm{mim}\right]\left[\mathrm{CH}_{3} \mathrm{COO}\right](99 \%)$, and 1-octyl-3methylimidazolium acetate $\left[\mathrm{C}_{8} \mathrm{mim}\right]\left[\mathrm{CH}_{3} \mathrm{COO}\right](99 \%)$ were purchased from Linzhou Keneng Material Technology Co., Ltd. Dimethyl sulfoxide DMSO was from Tianjin Kemiou Chemical Reagent Co. Ltd. These materials were used as received.

2.2. Preparation of $I L+D M S O$ Solvents. As an example, $\left[\mathrm{C}_{2} \mathrm{mim}\right]\left[\mathrm{CH}_{3} \mathrm{COO}\right]+\mathrm{DMSO}$ solvent was prepared by adding DMSO in dried $\left[\mathrm{C}_{2} \mathrm{mim}\right]\left[\mathrm{CH}_{3} \mathrm{COO}\right]$ with a given molar ratio $(2.5: 1)$ of DMSO to $\left[\mathrm{C}_{2} \mathrm{mim}\right]\left[\mathrm{CH}_{3} \mathrm{COO}\right]$ under stirring. $\left[\mathrm{C}_{4} \mathrm{mim}\right]\left[\mathrm{CH}_{3} \mathrm{COO}\right]+\mathrm{DMSO}$, $\left[\mathrm{C}_{6} \mathrm{mim}\right]\left[\mathrm{CH}_{3} \mathrm{COO}\right]+\mathrm{DMSO}$, and $\left[\mathrm{C}_{8} \mathrm{mim}\right]\left[\mathrm{CH}_{3} \mathrm{COO}\right]+$ DMSO solvents were prepared by using a similar process.

2.3. Dissolution of Cellulose. In a typical dissolution experiment, cellulose was added into a $25 \mathrm{~mL}$ colorimetric tube which contained $2.0 \mathrm{~g}$ of $\left[\mathrm{C}_{2} \mathrm{mim}\right] \mathrm{Ac}+\mathrm{DMSO}$, and the tube was sealed with parafilm. The tube was then immersed in an oil bath (DF-101S, Gongyi Yingyu Instrument Factory), and the bath temperature was controlled to be $25 \pm 0.5^{\circ} \mathrm{C}$. The mixture was heated and stirred at a given temperature. Additional cellulose was added until the solution became

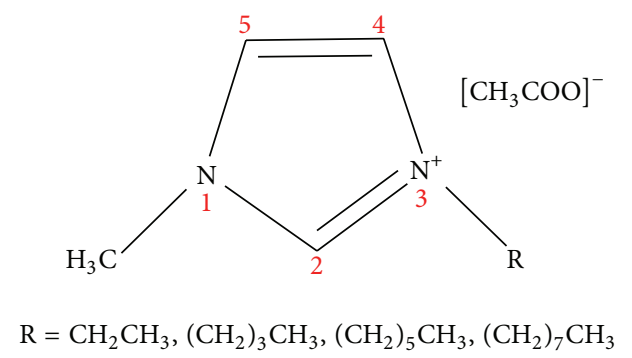

FIGURE 1: Schematic structures for the investigated ILs in the IL + DMSO solvents.

completely clear under polarization microscope (Nanjing Jiangnan Novel Optics Co., Ltd.). When cellulose became saturated, judged by the fact that cellulose could not be dissolved further within $2 \mathrm{~h}$, its solubility (expressed by gram per $100 \mathrm{~g}$ of solvent) at $25^{\circ} \mathrm{C}$ could be calculated from the amount of the solvent and cellulose added.

\section{Results and Discussion}

The solubility values of cellulose in IL + DMSO solvents at $25^{\circ} \mathrm{C}$ are shown in Table 1 . It can be seen from Table 1 that the alkyl chain length of imidazolium cation markedly affects the solubility of cellulose. Among the investigated IL + DMSO solvents, $\left[\mathrm{C}_{4} \mathrm{mim}\right]\left[\mathrm{CH}_{3} \mathrm{COO}\right]+\mathrm{DMSO}$ is the most efficient for the dissolution of cellulose. With the exception of $\left[\mathrm{C}_{4} \mathrm{mim}\right]\left[\mathrm{CH}_{3} \mathrm{COO}\right]+$ DMSO solvent, the solubility of cellulose decreases with increasing alkyl chain length in the order: $\left[\mathrm{C}_{2} \mathrm{mim}\right]\left[\mathrm{CH}_{3} \mathrm{COO}\right]+\mathrm{DMSO}>\left[\mathrm{C}_{6} \mathrm{mim}\right]\left[\mathrm{CH}_{3} \mathrm{COO}\right]+$ DMSO $>\left[\mathrm{C}_{8} \mathrm{mim}\right]\left[\mathrm{CH}_{3} \mathrm{COO}\right]+$ DMSO.

It is well known that the electron-donating capacity of alkyl group increases as alkyl chain length increases. Therefore, as the alkyl chain length in imidazolium cation increases, the electron cloud density of carbon atoms $\mathrm{C}_{2}$ and $\mathrm{C}_{4}$ (see Figure 1) bounded to nitrogen atom $\mathrm{N}_{3}$ decreases, which results in an increase in acidity of hydrogen atoms $\mathrm{H}_{2}$ and $\mathrm{H}_{4}$. Furthermore, the increased acidity of hydrogen atoms in imidazolium cation contributes to the hydrogen bond formation between acidic hydrogen and hydroxyl oxygen of cellulose and thus cellulose dissolution [5]. Therefore, the solubility of cellulose in $\left[\mathrm{C}_{4} \mathrm{mim}\right]\left[\mathrm{CH}_{3} \mathrm{COO}\right]+$ DMSO solvent is higher than that in $\left[\mathrm{C}_{2} \mathrm{mim}\right]\left[\mathrm{CH}_{3} \mathrm{COO}\right]+$ DMSO solvent. However, as alkyl chain length further increases, the steric hindrance of the hydrogen bond formation between acidic hydrogen and hydroxyl oxygen increases, and the hydrophilicity of imidazolium cation decreases [6]. Therefore, further increase in alkyl chain length conversely can cause a decrease in cellulose solubility. That is why the cellulose solubility decreases with increasing alkyl chain length in the order: $\left[\mathrm{C}_{4} \mathrm{mim}\right]\left[\mathrm{CH}_{3} \mathrm{COO}\right]+\mathrm{DMSO}>$ $\left[\mathrm{C}_{2} \mathrm{mim}\right]\left[\mathrm{CH}_{3} \mathrm{COO}\right]+\mathrm{DMSO}>\left[\mathrm{C}_{6} \mathrm{mim}\right]\left[\mathrm{CH}_{3} \mathrm{COO}\right]+$ $\mathrm{DMSO}>\left[\mathrm{C}_{8} \mathrm{mim}\right]\left[\mathrm{CH}_{3} \mathrm{COO}\right]+$ DMSO. Similar trend was also observed for the 1-alky-3-methylimidazolium chlorides in which $\left[\mathrm{C}_{n} \mathrm{mim}\right]^{+}$cation has varying alkyl chain lengths [13]. 
TABLE 1: The solubility (g per $100 \mathrm{~g}$ of solvent) of MCC in IL + DMSO solvents at $25^{\circ} \mathrm{C}$.

\begin{tabular}{llcc}
\hline Entry & \multicolumn{1}{c}{ Solvent } & $R_{\text {DMSO }}{ }^{\text {a }}$ & Solubility \\
\hline 1 & {$\left[\mathrm{C}_{2} \mathrm{mim}\right]\left[\mathrm{CH}_{3} \mathrm{COO}\right]+\mathrm{DMSO}\left(R_{\mathrm{DMSO}}=2.5: 1\right)$} & $2.5: 1$ & 12.5 \\
2 & {$\left[\mathrm{C}_{4} \mathrm{mim}\right]\left[\mathrm{CH}_{3} \mathrm{COO}\right]+\mathrm{DMSO}\left(R_{\text {DMSO }}=2.5: 1\right)$} & $2.5: 1$ & 15.0 \\
3 & {$\left[\mathrm{C}_{6} \mathrm{mim}\right]\left[\mathrm{CH}_{3} \mathrm{COO}\right]+\mathrm{DMSO}\left(R_{\text {DMSO }}=2.5: 1\right)$} & $2.5: 1$ & 1.0 \\
4 & {$\left[\mathrm{C}_{8} \mathrm{mim}\right]\left[\mathrm{CH}_{3} \mathrm{COO}\right]+\mathrm{DMSO}\left(R_{\mathrm{DMSO}}=2.5: 1\right)$} & $2.5: 1$ & 10.0 \\
\hline
\end{tabular}

${ }^{\mathrm{a}} R_{\mathrm{DMSO}}$ is the molar ratio of DMSO to IL.

In addition, it is also found that, at $25^{\circ} \mathrm{C}$, cellulose is not dissolved in all the ILs $\left[\mathrm{C}_{2} \mathrm{mim}\right]\left[\mathrm{CH}_{3} \mathrm{COO}\right]$, $\left[\mathrm{C}_{4} \mathrm{mim}\right]\left[\mathrm{CH}_{3} \mathrm{COO}\right], \quad\left[\mathrm{C}_{6} \mathrm{mim}\right]\left[\mathrm{CH}_{3} \mathrm{COO}\right], \quad$ and $\left[\mathrm{C}_{8} \mathrm{mim}\right]\left[\mathrm{CH}_{3} \mathrm{COO}\right]$. However, after DMSO was added in these ILs, respectively, cellulose becomes readily soluble. This is due to the fact that, upon adding DMSO in IL, DMSO serves to partially dissociate the strong ion pairs in IL into solvated cations and anions, and the solvated cations and anions in IL + DMSO solvent are more accessible to the hydroxyl proton of cellulose than those in neat IL, which is beneficial to the disruption of the hydrogen bonds in cellulose and thus to the cellulose dissolution $[11,12,14]$. This is the reason why cellulose becomes readily soluble in $\left[\mathrm{C}_{2} \mathrm{mim}\right]\left[\mathrm{CH}_{3} \mathrm{COO}\right]+\mathrm{DMSO}$, $\left[\mathrm{C}_{4} \mathrm{mim}\right]\left[\mathrm{CH}_{3} \mathrm{COO}\right]+\mathrm{DMSO},\left[\mathrm{C}_{6} \mathrm{mim}\right]\left[\mathrm{CH}_{3} \mathrm{COO}\right]+$ DMSO, and $\left[\mathrm{C}_{8} \mathrm{mim}\right]\left[\mathrm{CH}_{3} \mathrm{COO}\right]+$ DMSO solvents.

\section{Conclusions}

In this work, four cellulose solvents including $\left[\mathrm{C}_{2} \mathrm{mim}\right]\left[\mathrm{CH}_{3} \mathrm{COO}\right]+\mathrm{DMSO}, \quad\left[\mathrm{C}_{4} \mathrm{mim}\right]\left[\mathrm{CH}_{3} \mathrm{COO}\right]$ + DMSO, $\left[\mathrm{C}_{6} \mathrm{mim}\right]\left[\mathrm{CH}_{3} \mathrm{COO}\right]+$ DMSO, and $\left[\mathrm{C}_{8} \mathrm{mim}\right]\left[\mathrm{CH}_{3} \mathrm{COO}\right]+$ DMSO were prepared to investigate the effect of the alkyl chain length of imidazolium cation on cellulose solubility. With increasing alkyl chain length in imidazolium cation, the cellulose solubility decreases in the order: $\left[\mathrm{C}_{4} \mathrm{mim}\right]\left[\mathrm{CH}_{3} \mathrm{COO}\right]+\mathrm{DMSO}>$ $\left[\mathrm{C}_{2} \mathrm{mim}\right]\left[\mathrm{CH}_{3} \mathrm{COO}\right]+\mathrm{DMSO}>\left[\mathrm{C}_{6} \mathrm{mim}\right]\left[\mathrm{CH}_{3} \mathrm{COO}\right]+$ DMSO $>\left[\mathrm{C}_{8} \mathrm{mim}\right]\left[\mathrm{CH}_{3} \mathrm{COO}\right]+$ DMSO. This is mainly ascribed to the fact that the increasing alkyl chain length leads to an increase in the acidity of the hydrogen atoms $\mathrm{H}_{2}$ and $\mathrm{H}_{4}$ in imidazolium cation which contributes to the hydrogen bond formation between acidic hydrogen and hydroxyl oxygen of cellulose and thus cellulose dissolution. However, as alkyl chain length further increases, the steric hindrance of the hydrogen bond formation between acidic hydrogen and hydroxyl oxygen increases, and the hydrophilicity of imidazolium cation decreases, which goes against cellulose dissolution.

\section{Conflict of Interests}

The authors declare that there is no conflict of interests regarding the publication of this paper.

\section{Acknowledgment}

This work was supported financially by the National Natural Science Foundation of China (no. 21373078).

\section{References}

[1] H. Wang, G. Gurau, and R. D. Rogers, "Ionic liquid processing of cellulose," Chemical Society Reviews, vol. 41, no. 4, pp. 15191537, 2012.

[2] Y. Fukaya, A. Sugimoto, and H. Ohno, "Superior solubility of polysaccharides in low viscosity, polar and halogen-free 1,3dialkylimidazolium formates," Biomacromolecules, vol. 7, no. 12, pp. 3295-3297, 2006.

[3] A. R. Xu, J. J. Wang, and H. Y. Wang, "Effects of anionic structure and lithium salts addition on the dissolution of cellulose in 1-butyl-3-methylimidazolium-based ionic liquid solvent systems," Green Chemistry, vol. 12, no. 2, pp. 268-275, 2010.

[4] A. R. Xu, Y. B. Zhang, W. W. Lu, K. S. Yao, and H. Xu, "Effect of alkyl chain length in anion on dissolution of cellulose in 1butyl-3-methylimidazolium carboxylate ionic liquids," Journal of Molecular Liquids, vol. 197, pp. 211-214, 2014.

[5] J. M. Zhang, H. Zhang, J. Wu, J. Zhang, J. S. He, and J. F. Xiang, "NMR spectroscopic studies of cellobiose," Physical Chemistry Chemical Physics, vol. 12, no. 8, pp. 1941-1947, 2010.

[6] B. Lu, A. Xu, and J. Wang, "Cation does matter: how cationic structure affects the dissolution of cellulose in ionic liquids," Green Chemistry, vol. 16, no. 3, pp. 1326-1335, 2014.

[7] Y. J. Zhang, A. R. Xu, B. L. Lu, Z. Y. Li, and J. J. Wang, "Dissolution of cellulose in 1-allyl-3-methylimizodalium carboxylates at room temperature: a structure-property relationship study," Carbohydrate Polymers, vol. 117, pp. 666-672, 2015.

[8] N. Sun, M. Rahman, Y. Qin, M. L. Maxim, H. Rodríguez, and R. D. Rogers, "Complete dissolution and partial delignification of wood in the ionic liquid 1-ethyl-3-methylimidazolium acetate," Green Chemistry, vol. 11, no. 5, pp. 646-655, 2009.

[9] M. Zavrel, D. Bross, M. Funke, J. Büchs, and A. C. Spiess, "High-throughput screening for ionic liquids dissolving (ligno)cellulose," Bioresource Technology, vol. 100, no. 9, pp. 25802587, 2009.

[10] R. Rinaldi, "Instantaneous dissolution of cellulose in organic electrolyte solutions," Chemical Communications, vol. 47, no. 1, pp. 511-513, 2011.

[11] A. R. Xu, Y. J. Zhang, Y. Zhao, and J. J. Wang, "Cellulose dissolution at ambient temperature: role of preferential solvation of cations of ionic liquids by a cosolvent," Carbohydrate Polymers, vol. 92, no. 1, pp. 540-544, 2013.

[12] Y. L. Zhao, X. M. Liu, J. J. Wang, and S. J. Zhang, "Insight into co-solvent effect on cellulose dissolution in imidazolium-based ionic liquid solvent systems," Journal of Physical Chemistry B, vol. 117, no. 30, pp. 9042-9049, 2013. 
[13] J. Vitz, T. Erdmenger, C. Haensch, and U. S. Schubert, "Extended dissolution studies of cellulose in imidazolium based ionic liquids," Green Chemistry, vol. 11, no. 3, pp. 417-424, 2009.

[14] A. Xu, Y. Zhang, Z. Li, and J. Wang, "Viscosities and conductivities of 1-butyl-3-methylimidazolium carboxylates ionic liquids at different temperatures," Journal of Chemical \& Engineering Data, vol. 57, no. 11, pp. 3102-3108, 2012. 

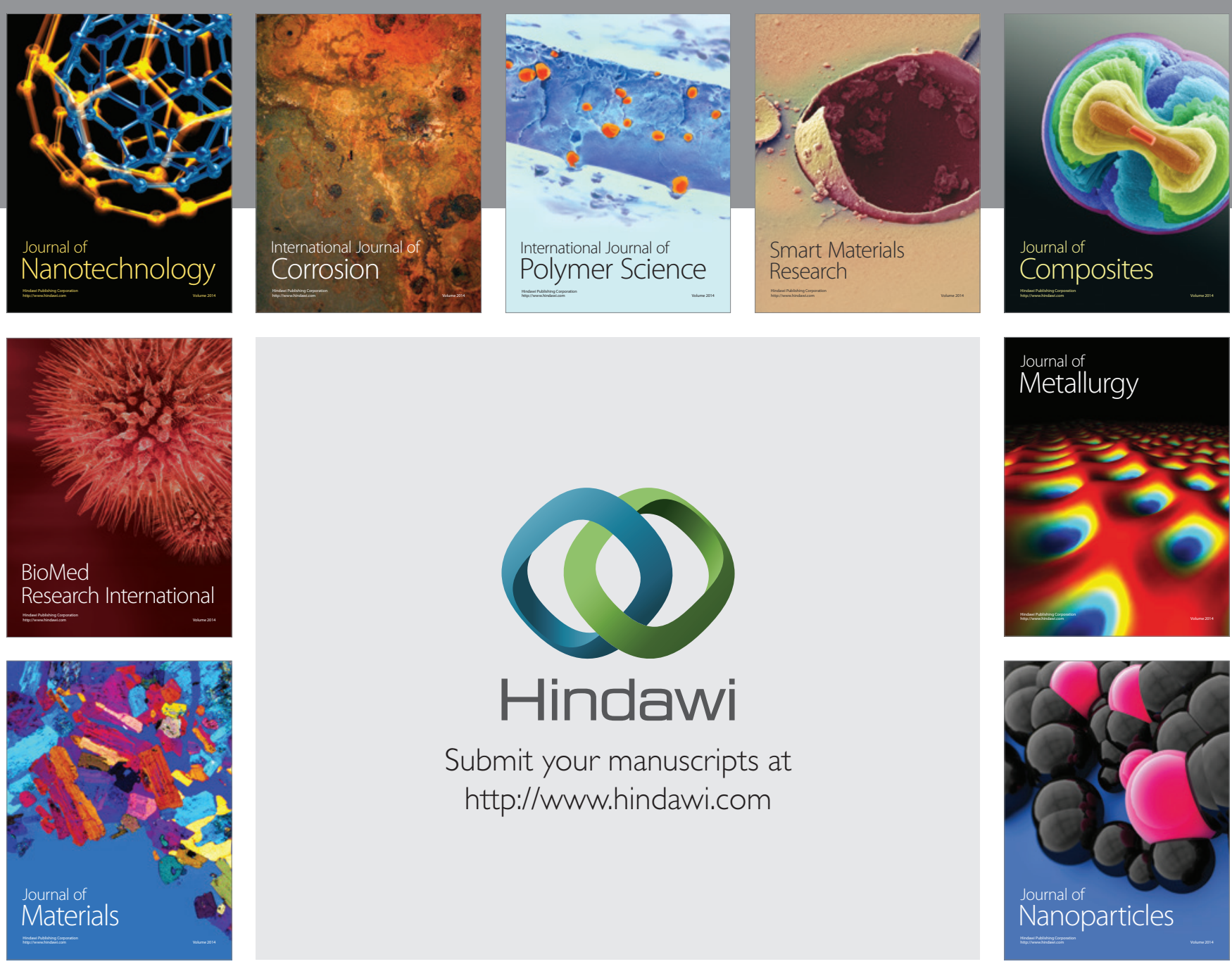

Submit your manuscripts at http://www.hindawi.com
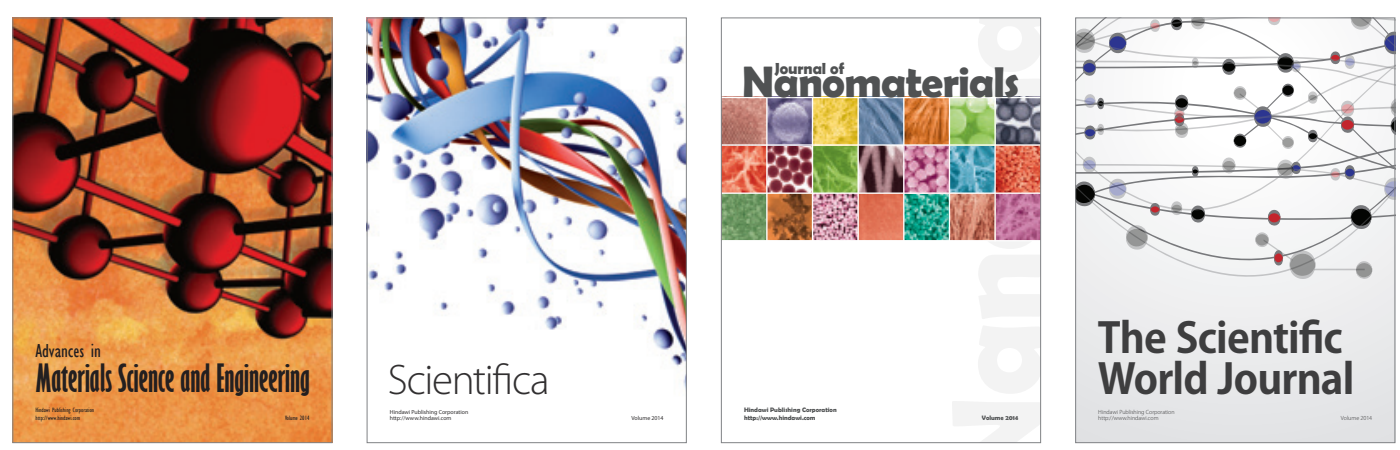

\section{The Scientific World Journal}
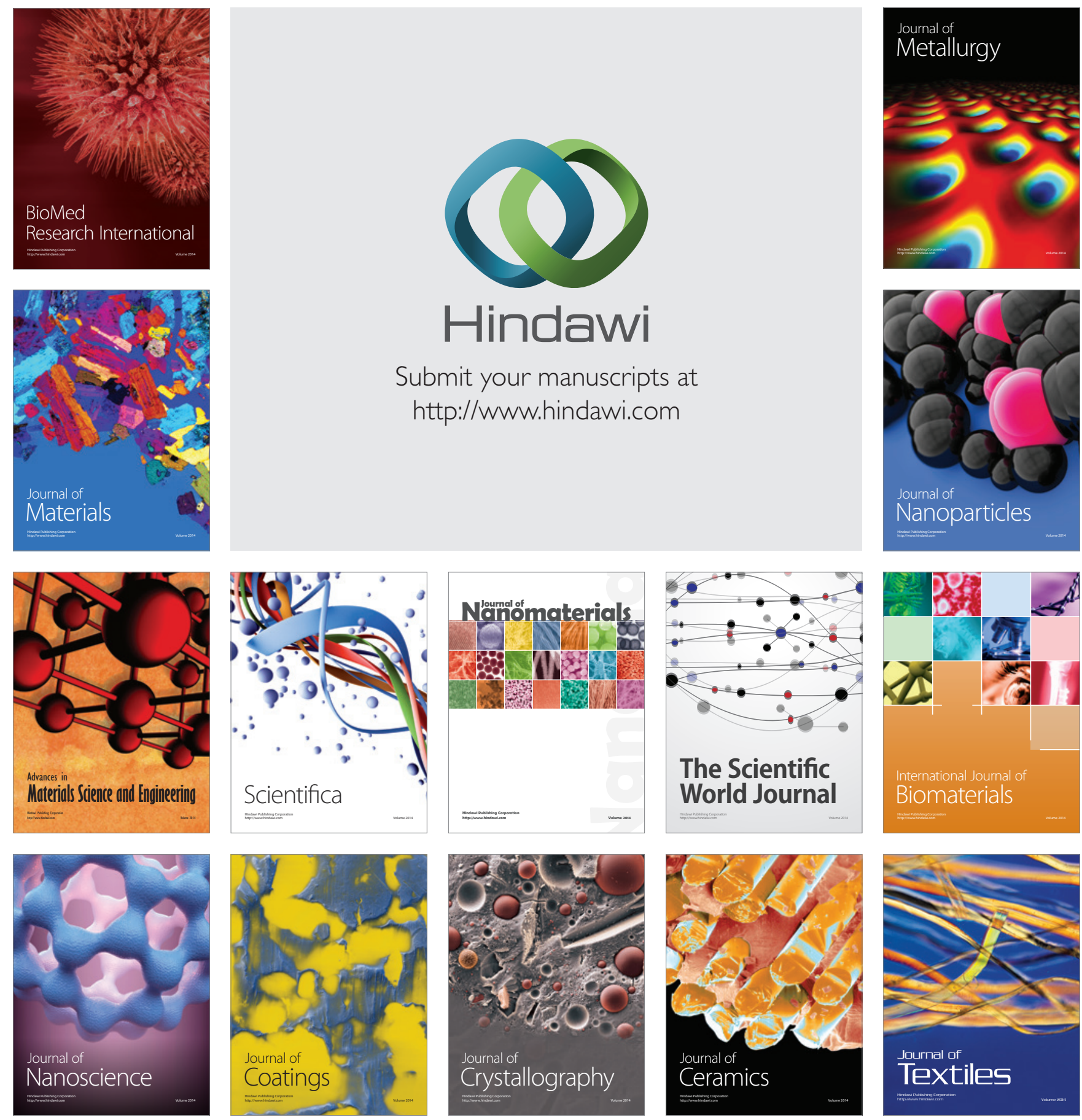